\title{
P-0984 HbA1C, a Potential Predictor of Fetal Outcome in Pregnancy with Diabetes
}

\author{
Ruma Sen Gupta ${ }^{1}$, Shahana Shermin² \\ 1. Registrar, 2. Senior Medical Officer, \\ Dept. of Gynae \& Obs., Ibrahim Medical College and BIRDEM General Hospital, Dhaka, Bangladesh.
}

\begin{abstract}
Background: Diabetes Mellitus poses substantial risk for the mother and fetus during pregnancy. Glycosylated $\mathrm{HbA} 1 \mathrm{C}$ is increased in chronic hyperglycemia and co-relates closely with an increased risk of fetal and neonatal complications. Objective: The present study was undertaken to determine the association of maternal serum $\mathrm{HbA} 1 \mathrm{C}$ level with fetal outcome. Materials and Methods: It was a prospective observational study carried out in the department of Obstetrics and Gynaecology in BIRDEM Hospital during the period of September 2006 to August 2007. During this study period, 100 pregnant patients with diabetes who attended or were admitted at BIRDEM Hospital were randomly selected. Estimation of serum $\mathrm{HbA} 1 \mathrm{C}$ level was done in all patients in each trimester. From each patient $5 \mathrm{cc}$ blood was taken and $\mathrm{HbA} 1 \mathrm{C}$ level was measured by enzymatic method. HbA1C level $<6 \%$ was considered as normal. The complications in antenatal period, in postpartum period, during labour and fetal outcome were studied. Results: In this study serum $\mathrm{HbA} 1 \mathrm{C}$ level was found raised in $83 \%$ of study subjects. Neonatal complications were higher in study subjects with uncontrolled $\mathrm{HbA} 1 \mathrm{C}$ level. Among the complications in uncontrolled group the highest incidence was of neonatal hypoglycaemia $(38.55 \%)$, followed by hyperbilirubinaemia $(33.73 \%)$, macrosomia (18.07\%) RDS $(12.05 \%)$, birth asphyxia $(12.05 \%)$, septicemia $(6.02 \%)$ and IUGR $(3.61 \%)$. Unexplained IUD occurred in $38.55 \%$ subjects in uncontrolled group. Conclusion: There is increasing evidence that raised level of maternal serum $\mathrm{HbA} 1 \mathrm{C}$ in antenatal period is associated with neonatal complications and by measuring $\mathrm{HbA} 1 \mathrm{C}$ level in each trimester, good glycaemic control in diabetic pregnancy can be achieved.
\end{abstract}

References:

1. Arias F. 1993. Risk of Pregnancy of mother \& fetus. In: Practical guide to high risk pregnancy and delivery. 2nd ed. Singapore : Harcourt Brace \& Co. Asia Pvt . Ltd, 280-98.

2. Gillmer MDG and Hurley PA. 1999. Diabetes \& Endocrinedisorders in pregnancy. In DK Edmonds editor, Dewhurst's textbook of obstetric and gynaecology for post graduates. $6^{\text {th }}$ edition, London N. Churchill Livingstone. Elsever, UK; 197-209.

3. Allen DW, Schroeder WA, Balog J. Observation on thechromatographic heterogeneity of normal adult and fetal heamoglobin. J Am Chem. 1958; 8:1628-34.

4. Trivelli LA, Ranney HM, Lai HT : Haemoglobin components in patient with diabetes mellitus. N Engl J Med 1971; 284:353 - 57.

5. Bunn HF. Evaluation of glycosylated heamoglobin indiabetic patients. Diabetes 1981;30:613-17.

6. Koenig RJ, Peterson $\mathrm{CH}$, Kilo $\mathrm{C}$, et al : $\mathrm{HbA} 1 \mathrm{C}$ as an indicatorof the degree of glucose intolerance in diabetes. N Engl J Med $1977 ; 296: 1060$.

7. Steel JM, Johnson FD, Smith AF, Duncan LJF, 5 yr. Experience of a prepregnancy clinic for pregestational diabetes. Am J ObstetGynecol.1998; 144: 774-76.

8. Kovilam O, Khoury J, Miodovnik M, et al. Spontaneouspreterm delivery in the type 1 diabetic pregnancy: The role of glycaemic control. J Mat-Fetal \& Neonatal Med 2002;11:245-48.

9. Banerjee S; Ghosh US; Banerjee D. Effect of tight glycaemic control on fetal complications in diabetic pregnancies. J Assoc Physicians India. 2004; 52:109-13.

10. Bracero LA, Haberman S, Byrne DW. Maternal glycaemiccontrol and umbilical artery Doppler velocimetry. J Matern Fetal Neonatal Med. 2002 Nov ; 12(5) : 342 48.

11. Raychaudhuri K, Maresh MJ. Glycaemic control throughout pregnancy and fetal growth in insulin-dependent diabetes. Obstet Gynecol. 2000;95(2):190-94

12. Frier BM, Fisher M. 2006. Diabetics Mellitus.IN : Boom NA Colledge NR, Walker BR, Hunter, JAA Editors. Davidson's Principle and Practice of medicine 20th ed. Edinburgh: Churchil Livingstone. 814-16.

13. Gabbay KH, Hasty K, Breslow JL, et al. Glycosylated haemologlobin and long term blood glucose control in diabetes mellitus. J.Clim Endocrinol Metab.1976; 44 : 859 -64 .

14. Nielsen GL, Moller M, Sorensen HT. HbA1c in early diabetic pregnancy and pregnancy outcomes: a Danish population based cohort study of 573 pregnancies in women with type 1diabetes. Diabetes Care. 2006; 29: 2612-16.

15. Deorary AK, Kabra SK, Paul VK, et al. Perinatal outcome of infants barn to diabetic mother. Indian Paediatr1991; $28: 1271-75$.

16. Beard R, Marsch M. Diabetes In de Swiet M, Medical disorder in obstetrics and practice 2nd edition. Blackwell Scientific publications. London 1989 : 584-32.
Table I: Age distribution of the study subjects $(n=100)$

\begin{tabular}{lcc}
\hline Age (in years) & Frequency & Percentage \\
\hline $20-25$ & 12 & 12 \\
$26-30$ & 48 & 48 \\
$31-35$ & 26 & 26 \\
$>35$ & 14 & 14 \\
\hline Mean age $\pm S D$ & \multicolumn{2}{c}{$29.77 \pm 4.52$} \\
\hline
\end{tabular}

Table II: Status of glycaemic control in late trimester of pregnancy in respect with $\mathrm{HbA1C}$ level $(n=100)$

\begin{tabular}{lcc}
\hline HbA1C level & Frequency & Percentage \\
\hline Controlled & 17 & $\mathbf{1 7}$ \\
Uncontrolled & 83 & $\mathbf{8 3}$
\end{tabular}

Table III: Distribution of fetal outcome in subjects with controlled and uncontrolled HbA1C

\begin{tabular}{lcc}
\hline Fetal outcome & $\begin{array}{c}\text { Controlled HbA1C } \\
(\mathbf{n = 1 7 )}\end{array}$ & $\begin{array}{c}\text { Uncontrolled HbA1C } \\
(\mathbf{n = 8 3})\end{array}$ \\
\hline Hypoglycaemia & $1(5.88 \%)$ & $32(38.55 \%)$ \\
Hyperbilirubinaemi & $2(11.76 \%)$ & $28(33.73 \%)$ \\
a & & \\
IUGR & $1(5.88 \%)$ & $3(3.61 \%)$ \\
RDS & - & $10(12.05 \%)$ \\
Macrosomia & - & $15(18.07 \%)$ \\
Septicaemia & $1(5.88 \%)$ & $5(6.02 \%)$ \\
Birth asphyxia & $1(5.88 \%)$ & $10(12.05 \%)$ \\
\hline
\end{tabular}

Table IV: Distribution of perinatal mortality in subjects with controlled and uncontrolled HbA1C level

\begin{tabular}{lcc}
\hline Perinatal outcome & $\begin{array}{c}\text { Controlled HbA1C } \\
(\mathbf{n = 1 7})\end{array}$ & $\begin{array}{c}\text { Uncontrolled HbA1C } \\
(\mathbf{n = 8 3})\end{array}$ \\
\hline Unexplained IUD & - & $32(38.55 \%)$ \\
Fresh Still Birth & $1(5.88 \%)$ & $6(7.22 \%)$ \\
\hline
\end{tabular}

Table V: Distribution of neonatal mortality in subjects with controlled and uncontrolled HbA1C level

\begin{tabular}{lcc}
\hline Neonatal outcome & $\begin{array}{c}\text { Controlled HbA1C } \\
(\mathbf{n = 1 7})\end{array}$ & $\begin{array}{c}\text { Uncontrolled HbA1C } \\
(\mathbf{n = 8 3})\end{array}$ \\
\hline Survived & $15(88.23 \%)$ & $74(89.15 \%)$ \\
Expired & $2(11.77 \%)$ & $9(10.85 \%)$ \\
\hline
\end{tabular}

